\title{
Expression of concern: Estimation of the laser cutting operating cost by support vector regression methodology
}

\author{
Srđan Jović ${ }^{1}$ - Aleksandar Radović ${ }^{1}$ Ž̌ivče Šarkoćević ${ }^{2}$. Dalibor Petković ${ }^{3} \cdot$ Meysam Alizamir ${ }^{4}$
}

Published online: 17 April 2019

○) Springer-Verlag GmbH Germany, part of Springer Nature 2019

The Editor-in-Chief of Applied Physics A is issuing an editorial expression of concern to alert readers that this article [1] shows substantial indication of irregularities in authorship during the publication process. This article contains overlap with the following articles amongst others [2-4]. All authors declare that they do not agree with the expression of concern.

\section{References}

1. S. Jović, A. Radović, Ž. Šarkoćević et al., Appl. Phys. A 122, 798 (2016). https://doi.org/10.1007/s00339-016-0287-1

2. T.A. Altameem, V. Nikolić, S. Shamshirband et al., Comput. Aided Des. 62, 57-63 (2015). https://doi.org/10.1016/j. cad.2014.10.003

3. O. Anicic, D. Petković, S. Cvetkovic, Renew. Sustain. Energy Rev. 56, 1122-1128 (2016). https://doi.org/10.1016/j.rser.2015.12.028

4. L. Olatomiwa, S. Mekhilef, S. Shamshirband et al., Nat. Hazards 77, 1055 (2015). https://doi.org/10.1007/s11069-015-1641-x

Publisher's Note Springer Nature remains neutral with regard to jurisdictional claims in published maps and institutional affiliations.

This comment refers to the article available online at https://doi. org/10.1007/s00339-016-0287-1.

Dalibor Petković

dalibortc@gmail.com

1 Faculty of Technical Sciences, University of Priština, Kneza Milosa 7, Kosovska Mitrovica 38220, Serbia

2 Visoka tehnička škola strukovnih studija Zvečan, Nušićeva 6, Zvečan 38227, Serbia

3 Department for Mechatronics and Control, Faculty of Mechanical Engineering, University of Niš, Aleksandra Medvedeva 14, Niš 18000, Serbia

4 Young Researchers and Elite Club, Hamedan Branch, Islamic Azad University, Hamedan, Iran 